\title{
Deadweight Loss in the Interest-based and the Interest-Free (Islamic) Microfinance Programs: A Comparative Analysis
}

\section{Basharat Hossain*}

Received: 07.01.2019

Accepted: 21.07.2019

DOI: $10.25272 /$ ijisef.509230

Type: Research Article

\begin{abstract}
This paper illustrates the deadweight loss in the interest-based Microfinance program compared to the interest-free or Islamic Microfinance program in terms of 'consumer' surplus, producer' surplus, loan price and the quantity demanded of the Microfinance loan. This article analyzes the secondary data on twenty Microfinance institutions of the nine countries of the world, and world microfinance data. Deadweight loss is demonstrated by using a numerical example and graphical presentation. The findings expose that consumer' surplus is at least three times higher, and producer' surplus is also higher in the Islamic Microfinance than the interest-based Microfinance program. In contrast the loan price is at least $142 \%-241 \%$ higher in interest-based Microfinance than the Islamic Microfinance. Consequently, the quantity demanded of Microfinance loan is higher in the Islamic Microfinance than the interest-based Microfinance. Finally this paper recommends for converting the interest-based Microfinance institution into the Islamic Microfinance institution to attain the wellbeing of microfinance member.
\end{abstract}

Keywords: Deadweight Loss, Interest-based Microfinance, Interest-free Microfinance, Islamic Microfinance, Consumer and Producer Surplus, Loan price.

Jel Codes: G21, I31, Z12

\footnotetext{
* Assistant Professor of Economics, Department of Business Administration, International Islamic University Chittagong, Chittagong, Bangladesh, E-mail: basharatdu@gmail.com, ORCID: https://orcid.org/0000-0001-6140-5392
} 


\section{Background and Motivation of the Study:}

The source of financing is the soul of investment to abolish the financial vulnerability of the people as well as an institution. The bank and non-bank financial institutions finance the people with collateral, whereas the Microfinance institution finances the people who have no collateral (Yunus, 2018). Accordingly, two types of Microfinance programs have been operating around the world. These are familiar as the interest-based Microfinance (conventional Microfinance) and the interest-free Microfinance (Islamic Microfinance) program, respectively.

However, despite having some structural differences, both Microfinance programs offer financial and non-financial services. Similarly, the group lending model is the most common process of microfinance transaction among both kinds of microfinance institutions (MFIs) around the world (Mughal, 2017; Grameen, 2018). However, regarding coverage, Islamic Microfinance industry only has $10 \%$ market share in the world microfinance industry. Besides, it secures only 1 percent market share to the world Islamic finance industry that has been experiencing a 17.82 percent growth rate per year (on average) during the 2007-2017 periods (GIFR, 2017). As well, at present, about 2,420 Microfinance institutions (Gonzalez, 2008), including 255 Islamic Microfinance institutions have been offering microfinance services in the world (CGAP 2017, GIFR 2017). Moreover, interest rate or profit rate is the primary motivation or financial benefit of the microfinance transaction. In this paper, the loan price will be synonymously used for the interest rate or profit rate. The interest rate (15-35\%) of the conventional or interest-based Microfinance institutions (Badruddoza, 2011; Rosenberg et al , $2013)$ is higher than the profit rate (0-15\%) of the Islamic Microfinance institutions around the world (Mannan (2015), Muslim Aid (2018), SSNF (2018), Al-arafah (2018), Exim bank (2018), TMSS (2018), IBBL (2018), Sadegh (2009).

At this circumstance, the policymakers and researchers raise the arguments that the Islamic Microfinance ensures the maximum benefit and welfare for its member by providing the exceptional products and services compared to the conventional Microfinance program. This is the primary motivation of this paper is to focus the welfare of the microfinance member by identifying the 'deadweight losses regarding loan price' through a comparison between the interest-free and the interest-based Microfinance program. The term 'deadweight loss' is synonymous with the word 'excess burden' or 'welfare loss'. It can be defined as the loss in total surplus that outcomes from a market inefficiency or distortion, such as a tax (Mankiw, 2014). Moreover, Paul Samuelson stated the deadweight loss as the fall in real income or loss of consumer' and producer' surplus that resulted from monopoly, quotas and tariffs, taxes, or other distortions like as inefficiency in resource allocation (Samuelson \& Nordhaus, 2010). Also, it can be delineated as the excess of the total harm done by the tax or any other economic distortion (Black, 1997). Finally, it can be delineated as the loss of overall well-being or the societal surplus or consumer' utility/surplus or producers' surplus that is stimulated by the economic inefficiency or the failure of optimal resource allocation \& equilibrium. For example, 
deadweight loss is the outcomes of tax, subsidy, externality, price ceiling or price floor, and monopoly pricing.

Finally, this paper presents the deadweight loss in the microfinance program on the subject of consumer' surplus, producer' surplus, and quantity demand of loan. The detailed methodology has been introduced in the section four. Besides, objective and the literature review have been described in section two and three, respectively. Moreover, determinants, as well as the indicators of the deadweight loss in conventional Microfinance, are discussed in section five. As well, key findings, recommendations, and conclusion are presented in section six, seven, and eight accordingly.

\section{Objective:}

The prime aim of this article is to detect and expose the evidences of the deadweight losses in the conventional Microfinance program in Bangladesh and the world. More precisely, this paper investigates and highlights the deadweight losses in the traditional (interest-based) Microfinance program by comparing it with the Islamic Microfinance (interest-free) program. The specific objectives are:

a) To expose the operational differences between the interest-based and interest-free Microfinance program in terms of nature and products.

b) To identify and highlight the deadweight losses/economic losses/welfare losses in the interest-based Microfinance program in terms of consumers' surplus, producers' surplus and the quantity demanded of the Microfinance loan.

\section{Methodology}

\section{Data:}

This paper is a comparative study between the interest-based and the interest-free microfinance program. It has been designed based on the secondary data on the twenty Microfinance institutions of the nine countries of the world, and world microfinance data. This paper uses the numerical example and graphical presentation to determine the deadweight loss. Furthermore, the primary sources of secondary data were the Global Islamic Finance data (2012-2017), websites of Microfinance institutions, statistics from the Bangladesh Microfinance regulatory authority, and so more.

\section{Methods of Analysis:}

To determine the deadweight loss, this study uses the three indicators these are (a) consumer' surplus, (b) producer' surplus and (c) the quantity demanded of the loan from Microfinance institutions. To measure these indicators, the loan price or interest rate or profit rate, the nature of the loan, contribution to real asset building, diversion of cash loan, and the charity tools were considered in this study. To illustrate the deadweight loss, the numerical example and graphical presentation are used in this study. 
However, renowned economists also employed the technique of consumer' surplus and producer' surplus to determine the deadweight loss. Samuelson and Nordhaus (2010) apply the consumer' surplus and producer' surplus to identify the deadweight loss or net economic loss through graphical comparison between the perfectly competitive market and the monopoly market. Moreover, Webster (2003) also incorporates the concept of deadweight loss in the forms of consumer' and producer' surplus to show the welfare scenario of monopoly. He also described it mathematically. Besides, Samuelson and Stephen (2011) explained the deadweight loss regarding consumer' surplus resulted for the tariff and quota in the market. Furthermore, Bishop (2004) discussed the deadweight loss of taxation in terms of consumer' income and asset loss.

As well, after considering the above literature, this study measured the deadweight loss regarding the consumer' surplus and producer' surplus. The consumer' surplus is calculated by "the difference between the willingness to pay by the consumer and the amount actually paid" Also, producer' surplus is fixed by "the difference between the sales revenue (at the equilibrium price) and the cost of the producer."

\section{Literature Review}

Several studies have been accomplished on the field of the interest-free or Islamic Microfinance and interest-based or conventional Microfinance in Bangladesh and the world perspective. This paper employs a new idea 'the deadweight losses in the traditional microfinance program regarding consumer' and producer' surplus, loan price, and the quantity demanded of a Microfinance loan. The related researches have been discussed below.

Hossain (2019) presents a Waqf based Islamic Microfinance model for the slum dwellers. He proposed the Rehabilitation for the slum dwellers firstly, then secondly, offering the Islamic Microfinance for them. Zubair Mughal (2017) explains the funding sources of the interest-free Islamic Microfinance program. Abdullah et al. (2017) compare the IBBL-RDS Islamic Microfinance program with the Grameen bank. Alamgir et al. (2015) compare the IBBL-RDS Islamic Microfinance program with the conventional Microfinance of BURO Bangladesh and stated that IBBL applied Islamic modes of investment successfully. Widiarto and Emrouznejad (2015) examine the societal plus financial efficacy of interest-free microfinance institutions by comparing with the two interest-based microfinance institutions. Saaid Ali (2015) discusses the financing procedure of Islamic Microfinance for the best and effective outcome in alleviating poverty. Ismail et al. (2015) present a human resource proficiency model for interest-free Microfinance institution. Mahmood et al. (2014) inspect the efficiency of nine conventional and three Islamic MFIs. They find that the efficiency of Islamic MFIs is higher in comparison to the traditional MFIs. Haneef et al. (2014) propose a Microfinance model for poverty elimination by using Waqf for the OIC countries. Ashraf et al. (2014) measure the performance of the 754 MFIs from 83 countries (33 OIC countries) regarding coverage, loan repayment, profitability, and overall financial performance. They find significant results. Riwajanti (2013) describes the different model of poverty reduction by Islamic microfinance 
and its performance elaborately. Moreover, Ben Abdelkader and Ben Salem (2013) analyzed the performance of Islamic vs. conventional Microfinance institution and showed the differences in terms of member and performance. Bui (2013) presented the multidimensional usages of Microfinance among the conventional and Islamic microfinance members in Jordan. This research paper showed that how the choices of the traditional and Islamic members vary in determining the commercial investments, family development schemes, and the daily consumptions materials. El-Komi (2013) examines the information asymmetry in Islamiccompliant microfinance products. Norma (2012) in her article, at first scrutinizes the practices of interest-free Microfinance program of Bangladesh, and then finally, evaluates the operation of Amanah Ikhtiar Malaysia (AIM), the leading MFIs in Malaysia. She uses primary data on AIM. Masyita and Ahmed (2011) scrutinize the growth rate of conventional and Islamic microfinance regarding the choices and observations of the five hundred eighty-one microfinance members of Indonesia. Rahman (2010) discloses the potentials of Qard Hasan, Murabahah, and Ijarah instruments for the Islamic Microfinance. Akhter et al. (2009) discourse the contribution of Islamic Microfinance in lessening poverty by analyzing the success of Akhuwat Islamic microfinance in Pakistan. They propose to integrate the Islamic Microfinance with Zakah, Waqf, Takaful, and with NGOs, NPOs to increase its effectiveness in suppressing poverty. Obaidullah (2008), in his book, discusses the framework of Islamic microfinance as a proof of Islamic approaches for poverty alleviation. Seibel (2008) raises the issues of challenges for Islamic microfinance institutions regarding structural diversity, regulatory, and supervisory framework in the Indonesian perspective. Furthermore, Obaidullah and Khan (2008) explain the foundation, infrastructure, provider, guideline and supervision of Islamic Microfinance institutions; and the role of the donor as well as a financial institution to develop the Islamic microfinance institution. Wilson (2007) depicts the structure, instruments of an Islamic Shariah based microfinance program. Wajdi Dusuki (2007) highlights the potentiality of Islamic microfinance under Islamic banking. He shows that Islamic banks can incorporate the Islamic microfinance program for alleviating poverty by its excess liquidity, but must maintain banks' sustainability. Ubaidullah (2007) discusses the effect of interest-free microfinance on the poverty reduction in Indonesia, Bangladesh, and Turkey. Rahman (2007) describes the potentials of the Islamic Microfinance for socio-economic progress of the underprivileged people and micro-enterprises. Because it does not charge interest/Riba but provides Qard Hasan (benevolent loan). Ahmed (2002) proposes the theoretical and practical framework of Islamic Microfinance by illustrating the empirical evidence from three Islamic Microfinance institution of Bangladesh.

The above mentioned previous studies covers the issues of financing, institutional challenges as well as regulatory framework, supervising and Shariah compliance, potentials and Shariah scheme for Islamic Microfinance, case studies on Islamic Microfinance institutions (IMFIs), success of Islamic Microfinance in the eliminating of poverty, performance of Islamic Microfinance, information asymmetry in the Islamic microfinance products, and finally the comparison between the interest-free Microfinance and interest-based microfinance 
respectively. But none of these studies covers the issue of deadweight loss in the traditional microfinance program. This is the central point of this paper. This paper compares the Islamic Microfinance with the conventional Microfinance and analyzes the deadweight loss in the traditional scheme of microfinance regarding consumer' and producer' surplus, loan price, and the quantity demanded of a Microfinance loan. This is the new addition in the field of Microfinance research.

\section{Nature, Structure, and Proliferation of Microfinance (Interest-based and Interest-free) Program:}

Microfinance involves both financial and non-financial services. It also synonymously used as microcredit. The collateral-free Micro-loans, Micro-savings, money transfer, and microinsurance, are the primary forms of financial services. Also, Microfinance institution offers children and women's education and training program, infants and maternity care, sanitation, etc. (FINCA 2018, Grameen 2018a, BRAC 2018). However, the interest-based microfinance institutions operate financial services by charging or paying interest or usury on principle amount of loaned money (Yunus and Jolis, 2006). Whereas non-financial services are being offered at a nominal price or free, depending on the availability of the funds from the donor agencies (UNDP, 2010). Figure 1-3 illustrates the financial, operational framework of the interest-based microfinance institutions.

\begin{tabular}{|c|c|c|c|}
\hline \multicolumn{2}{|c|}{ Figure 1: Microcredit Operation } & \multicolumn{2}{|c|}{ Figure 2: Micro-Savings Operation } \\
\hline \multicolumn{2}{|c|}{$\begin{array}{l}\text { Conventional/Interest-based Microfinance } \\
\text { Institutions }\end{array}$} & \multicolumn{2}{|c|}{$\begin{array}{c}\text { Conventional/Interest-based Microfinance } \\
\text { Institutions }\end{array}$} \\
\hline & $\begin{array}{l}\text { Service charge }+ \text { Interest } \\
\text { on Microcredit (Cash) }\end{array}$ & $\uparrow$ & $\begin{array}{c}\downarrow \\
\text { Interest on Microsavings } \\
(\text { Cash })\end{array}$ \\
\hline $\begin{array}{l}\text { Microcredit } \\
\text { (Cash) }\end{array}$ & $\rightarrow$ Borrowers/member & $\begin{array}{l}\text { Microsavings } \\
\text { (Cash) }\end{array}$ & $\leftarrow$ - Borrowers/ member \\
\hline
\end{tabular}

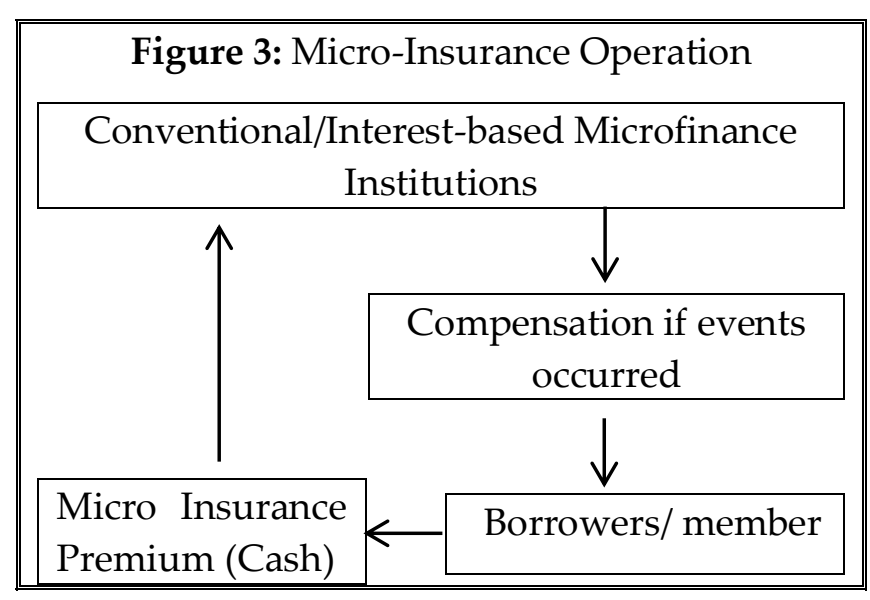

Source: Sketched by the Author 
Similarly, like as interest-based Microfinance program, interest-free Microfinance program also offers both financial and non-financial services. But its operational framework is quite different that is run by the profit-loss sharing system. The financial services are highly concentrated in the trade or buying and selling business, followed by the benevolent loan (profit free loan). In the trade, the interest-free Microfinance institutions mainly sell the goods to its members instead of the cash loan, and charges profit on the goods (as the market rate) (Sadegh, 2009). This is the main functional dissimilarity between the interest-free and the interest-based Microfinance program.

Also, interest-free Microfinance institutions make available the profit-free loan ( Qard HasanBenevolent loan) for its members for which no profit will be claimed, but the member only will repay the principal amount (Khan,1990). The figure 4-7 reveals the microfinance operation of the interest-free Microfinance institutions. Moreover, in the interest-free Microfinance program, the microcredit operation is fully concentrated to buying and selling system, that is run by the Bai-Murabahah (Cost plus Profit sales or deferred sales), Hire purchase (joint purchase and ownership transfer through rent ) and Bai-Salaam (Future Sale) contracts (See Figure 4) (Mughal, 2017; Islami bank, 2018).

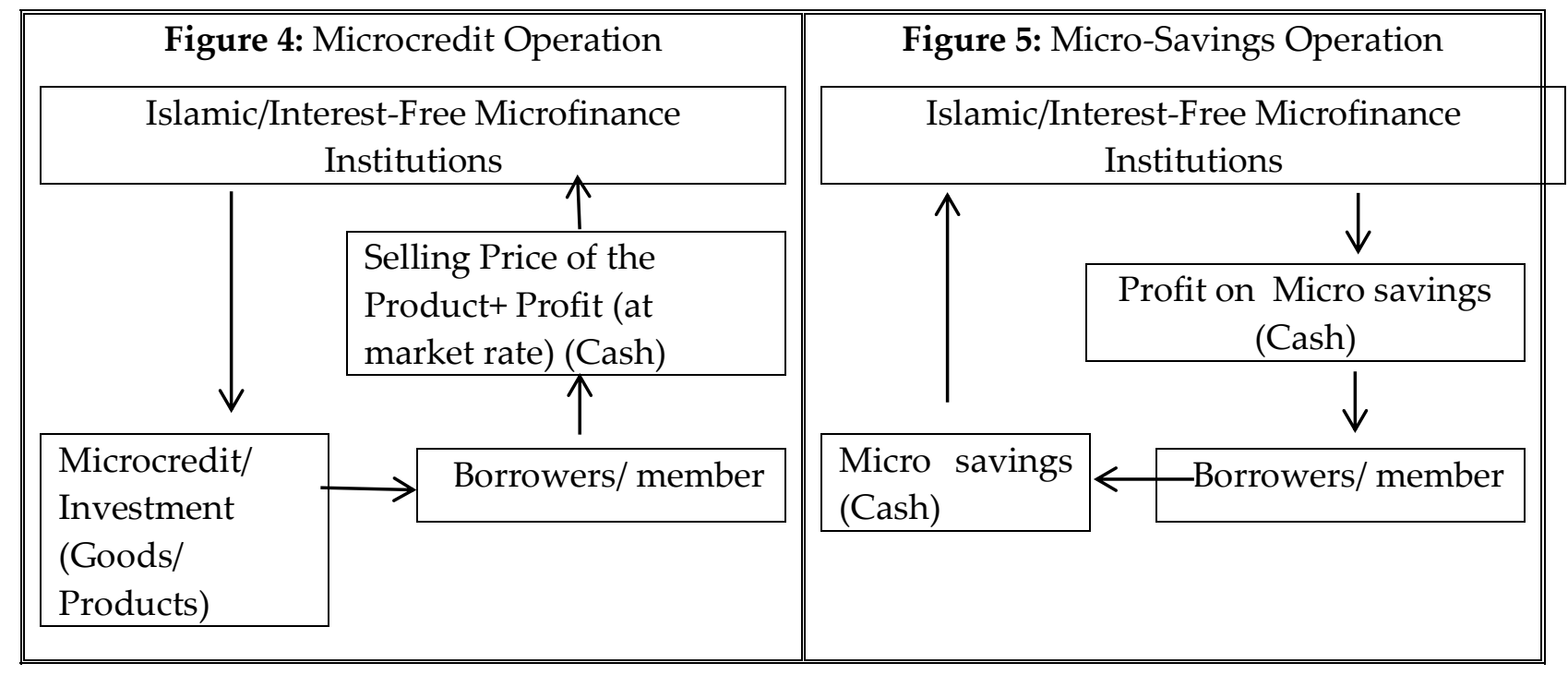

Source: Sketched by the Author

In savings framework, interest-free Microfinance applies Mudaraba (Trust Partnership) and Musharakah (Equity Partnership) modes /contract under the Islamic shariah (Islami Bank, 2018a). Figure 5 illustrates this function. 
Also, the profit free loan system is offered through the Qard Hasan (Benevolent loan) modes. It should be mentioned out that, interest-free microfinance program abide by the principles of Islamic economics where profit satisfaction is highly appreciated and recommended rather than the profit maximization (Qarz Al-Hasaneh Mehr Iran Bank, 2017). This is why; the benevolent loan is a mandatory contract to be executed for interest-free microfinance program that makes it superior to the interest-based microfinance program. This framework is depicted in figure 6.

Furthermore, Micro-insurance program is known as micro-takaful in the interest-

Figure 6: Profit Free Loan Operation

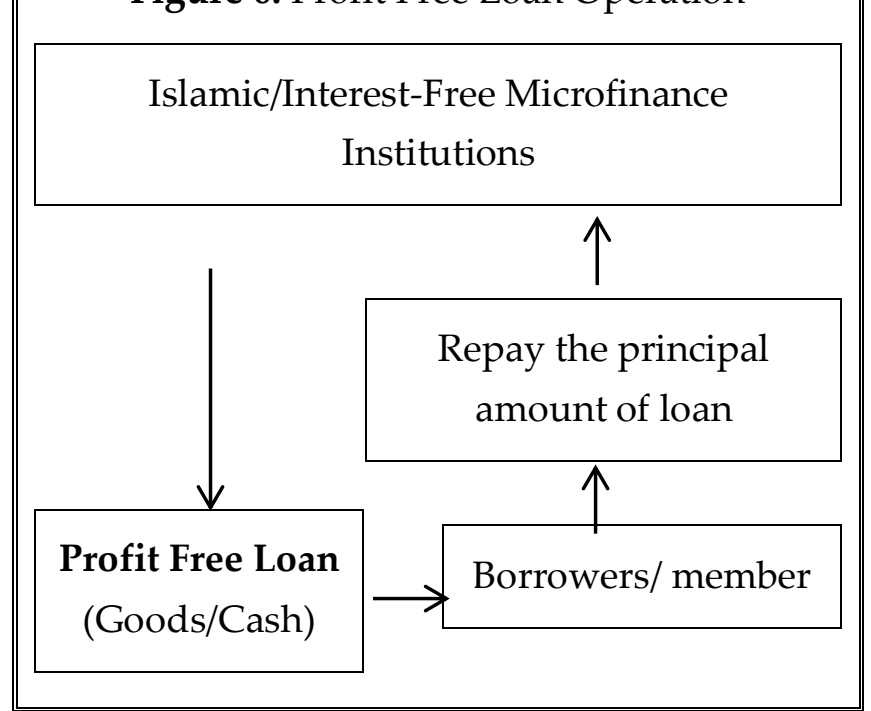
free microfinance program. Not only in the terminology, but it (micro-takaful) also differ from the micro-insurance regarding the procedure that is revealed in figure 7. In takaful system, the members' premium will be invested and refunded with profit to the member. For any damages, he will be compensated from donation funds that will be formed by the mandatory donations of

Figure 7: Micro-Takaful Operation

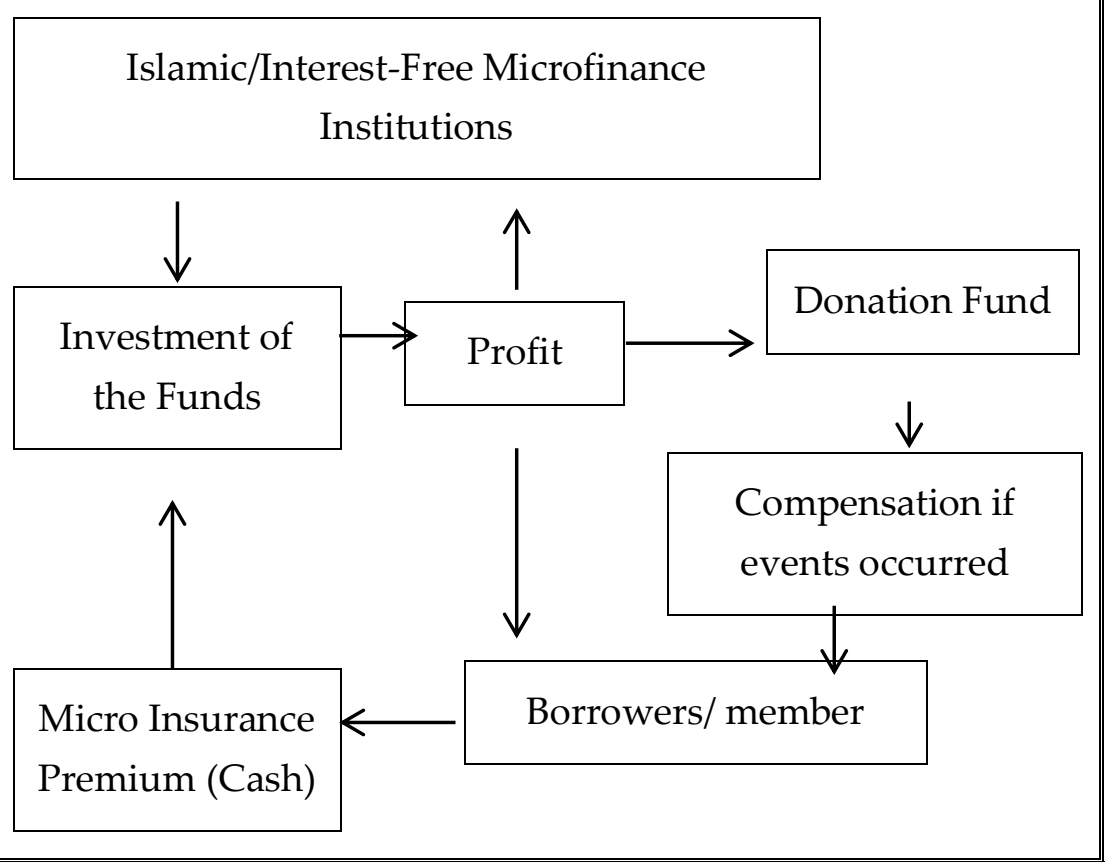
all members of the micro takaful from their premiums' profit or premium (ISRA, 2012). In contrast, in the microinsurance scheme of interest-based microfinance program, the member will be compensated if, and only if the accident occurs, otherwise, all premiums will be added to the company profit (Rejda and McNamara 2013; Shrikrishna, 2009).

However, Table-1 exhibits the dissimilarities between interest-based and the interest-free Microfinance Program. 
Deadweight Loss in the Interest-based and the Interest-Free (Islamic) Microfinance Programs: A Comparative Analysis

Table 1: Differences between Conventional Microfinance and Islamic Microfinance'

\begin{tabular}{|c|c|c|}
\hline Basis & $\begin{array}{c}\text { Conventional Microfinance } \\
\text { (Interest-based) }\end{array}$ & $\begin{array}{l}\text { Islamic Microfinance } \\
\text { (Interest-free) }\end{array}$ \\
\hline Funding sources & $\begin{array}{l}\text { National and International } \\
\text { donors, multilateral, bilateral } \\
\text { and domestic organizations, } \\
\text { private sector, central banks, } \\
\text { government. }\end{array}$ & $\begin{array}{l}\text { Islamic charitable sources: Zakah, } \\
\text { sadaqah and waqf. Islamic financial } \\
\text { institutions, Religious institutions, } \\
\text { foreign donors, national agencies, } \\
\text { private sector, Members' Savings }\end{array}$ \\
\hline \multirow[t]{2}{*}{ Basic Function } & $\begin{array}{l}\text { Financial services: Microcredit } \\
\text { through Lending-borrowing, } \\
\text { Micro-savings, Micro } \\
\text { insurance }\end{array}$ & $\begin{array}{l}\text { Financial services: Profit-Loss } \\
\text { sharing based Business, buying \& } \\
\text { selling at a lower profit rate, Interest } \\
\text { free Loan/ benevolent loan/ Qard al- } \\
\text { hasanah } \\
\text { Micro-savings, Micro insurance } \\
\text { (Takaful) }\end{array}$ \\
\hline & $\begin{array}{l}\text { Nonfinancial services: } \\
\text { Education, healthcare, child } \\
\text { and maternal care etc. }\end{array}$ & $\begin{array}{l}\text { Nonfinancial services: Education, } \\
\text { healthcare, child and maternal care } \\
\text { etc. }\end{array}$ \\
\hline Basis of Loan & Interest rate & $\begin{array}{l}\text { Profit-Loss sharing, } \\
\text { Profit rate on buying selling } \\
\text { Interest free Loan } \\
\text { Religious charity }\end{array}$ \\
\hline $\begin{array}{c}\text { Loan/Fund } \\
\text { disbursement }\end{array}$ & Cash & Goods/Products \\
\hline Model & Group Lending and others & Individual and Group Investment, \\
\hline $\begin{array}{l}\text { Method of Loan } \\
\text { Recovery }\end{array}$ & $\begin{array}{l}\text { Group Liability, forces by the } \\
\text { Group or unit }\end{array}$ & $\begin{array}{l}\text { Group Liability, Group assurance, } \\
\text { Islamic moral values }\end{array}$ \\
\hline $\begin{array}{l}\text { Socioeconomic } \\
\text { advancement } \\
\text { project }\end{array}$ & $\begin{array}{l}\text { material and societal } \\
\text { advancement }\end{array}$ & $\begin{array}{l}\text { Spiritual motivation that incorporates } \\
\text { moral behavior and social values } \\
\text { from religion }\end{array}$ \\
\hline
\end{tabular}

Source: UNDP (2010) and compiled by the author from different sources

\section{Deadweight Loss in the Conventional Microfinance Program}

\subsection{Determinants of the Deadweight Loss in the Conventional Microfinance:}

After scrutinizing the different products and services of the interest-based and interest-free Microfinance program, this section presents the determinants of the deadweight loss, as follows.

a) Profit-Loss Sharing: To encourage the underprivileged people, Islamic Microfinance applied the profit-loss sharing business that is known as Mudaraba (trust partnership) and 
Musharakah (equity partnership). In Mudarabah mode, the member of the Microfinance program invests fund with MFIs, then profit and loss are shared according to an agreed ratio. Islamic MFIs offers the maximum benefit in this scheme. Also, in Musharakah mode, both parties provide the capital, and then profit and losses are shared according to the capital ratio. On the contrary, conventional MFIs have no option of profit-loss sharing business. Thus, interest-free Microfinance produces a welfare loss by squeezing the investment options for the Microfinance borrower.

b) Charging the Interest Rate: the average loan price or the average loan interest rate is at least $142.05 \%$ (Bangladesh) and 241.84\% (world) higher in the conventional Microfinance than the Islamic Microfinance (see Box-1 in the Appendix).

Moreover, Islamic Microfinance does not offer any interest but offer only profit rate based on buying and selling. The table- 2 and 3 depict the interest rate scenario among the conventional and the Islamic Microfinance institution in Bangladesh and the world. Moreover, InM (2016) showed that the effective interest rate (on the weekly installment) in Bangladesh is at least $150 \%$ higher than the declared interest rate. The loan price scenario reveals the devastating welfare loss of the borrower in the interest-based Microfinance compared to the Islamic Microfinance.

Table 2: List of Loan Price in the Conventional (Interest based) and Islamic Microfinance (Interest Free) Institutions in the world

\begin{tabular}{|c|c|c|c|c|}
\hline & Name & Profit Rate & Country & Reference \\
\hline \multicolumn{5}{|c|}{ Islamic / Interest Free Microfinance Institutions } \\
\hline 1. & Muslim Aid Bangladesh & $\begin{array}{l}\text { Quard Hasan } \\
0 \%\end{array}$ & Bangladesh & Muslim Aid (2018) \\
\hline 2. & $\begin{array}{lr}\text { Islami Bank Bangladesh } \\
\text { Limited, } & \text { Rural } \\
\text { Development } & \text { scheme } \\
\text { (RDS), Urban } & \text { Poor } \\
\text { Development } & \text { Scheme } \\
\text { (UPDS) } & \end{array}$ & $\begin{array}{l}12.5 \% \text { (2.5\% } \\
\text { rebate on Timely } \\
\text { repayment }), \\
\text { Quard } \\
\text { Hasanah }\end{array}$ & Bangladesh & IBBL (2018) \\
\hline 3. & $\begin{array}{l}\text { Al-arafahIslami Bank, } \\
\text { Krishi o } \\
\text { KhudroBiniogProkolpo } \\
\text { (Microfinance) }\end{array}$ & $\begin{array}{l}15 \% \quad \text { (Reducing } \\
\text { balance method) }\end{array}$ & Bangladesh & Al-arafah (2018) \\
\hline 4. & $\begin{array}{l}\text { Exim Bank Microfinance: } \\
\text { Agricultural and Rural } \\
\text { investment }\end{array}$ & $9 \%$ & Bangladesh & Exim bank (2018) \\
\hline 5. & $\begin{array}{l}\text { Akhuwat Islamic } \\
\text { microfinance (AIM) }\end{array}$ & $0 \%$ & Pakistan & Akhuwat (2018) \\
\hline
\end{tabular}


Deadweight Loss in the Interest-based and the Interest-Free (Islamic) Microfinance Programs: A Comparative Analysis

\begin{tabular}{|c|c|c|c|c|}
\hline 6. & $\begin{array}{l}\text { The Qarz Al-Hasaneh } \\
\text { Mehr Iran Bank }\end{array}$ & $1-4 \%$ & Iran & QMB (2018) \\
\hline 7. & Wasil foundation & $0-10 \%$ & Pakistan & $\begin{array}{l}\text { Wasil foundation } \\
(2018)\end{array}$ \\
\hline 8. & Islamic Relief & $0 \%$ (Qard Hasan) & Bangladesh & Islamic Relief (2018) \\
\hline 9. & Islamic Relief & 0\% (Qard Hasan) & Pakistan & Islamic Relief (2018a) \\
\hline \multirow[t]{2}{*}{10.} & Ebdaa Microfinance bank & $1.5 \%-15 \%$ & Sudan & Ebdaa bank (2018) \\
\hline & \multicolumn{3}{|c|}{ Conventional / Interest based Microfinance Institutions } & \\
\hline 1. & Grameen Bank & $20 \%$ & Bangladesh & Yunus (2018) \\
\hline 2. & BRAC & $26 \%$ & Bangladesh & BRAC (2018) \\
\hline 3. & ASA & $25 \%$ & Bangladesh & ASA (2018) \\
\hline 4. & Buro Bangladesh & $15-20 \%$ & Bangladesh & Buro (2018) \\
\hline 5. & Shakti Foundation & $27 \%$ & Bangladesh & Shakti (2018) \\
\hline 6. & CARD Bank, Inc. & $28 \%$ & Philippines & Card Bank (2017) \\
\hline 7. & $\begin{array}{l}\text { "Mitra Bisnis Keluarga" } \\
(\mathrm{MBK}), \text { or "Family } \\
\text { Business Partners" }\end{array}$ & $20 \%$ & Indonesia & MBK (2018) \\
\hline 8. & Grameen koota & $21 \%$ & India & $\begin{array}{l}\text { Grameen koota } \\
(2018)\end{array}$ \\
\hline 9. & Lead Foundation & $16-21 \%$ & Egypt & $\begin{array}{ll}\text { Lead } & \text { Foundation } \\
(2016) & \end{array}$ \\
\hline 10. & Vitas Lebanon & $27.5 \%-41.27 \%$ & Lebanon & Vitas Lebanon (2018); \\
\hline
\end{tabular}

Source: Compiled by the Author

Table 3: Microcredit Interest Rate (2004-2011) in the World by Region

\begin{tabular}{|c|l|l|l|}
\hline S1 no & \multicolumn{2}{|l|}{ Region } & Interest rate \\
\hline 1. & MENA & Middle East and North Africa & $31-32 \%$ \\
\hline 2. & Asia & South Asia, & $25-26 \%$ \\
\hline 3. & EAP & East Asia and the Pacific & $27 \%$ \\
\hline 4. & Africa & Sub-Saharan Africa & $31-33 \%$ \\
\hline 5. & LAC & Latin America and Caribbean & $31-32 \%$ \\
\hline 6. & ECA & Eastern Europe and Central Asia & $28-29 \%$ \\
\hline 7. & World & World & $27 \%$ \\
\hline
\end{tabular}

Source: Rosenberg, Gaul, Ford, \& Tomilova (2013)

c) Interest-free Loan/ Benevolent Loan/ Qard al-Hashanah: Islamic Microfinance offers Interest-free loan or the benevolent loan or Qard al-Hashanah. In this mode, the recipient has to repay the principle amount of money only, but no extra money as either interest or profit. In contrast, conventional MFIs have no option of the interest-free loan. It produces welfare loss for microfinance member in the interest-based microfinance. 
d) Real Asset Building: The most essential point is that Islamic Microfinance institutions contribute to building real asset more than conventional MFIs. Because Islamic MFIs always transfer goods or business means or materials instead of a cash/loan. It ensures real asset development. Whereas in traditional Microfinance, it is optional to handover products; instead, it lends the cash at a particular interest rate.

e) Fund/Loan Diversion: Since the conventional MFIs transfer the money as lending to its recipients. So there is a vast possibility to divert funds to another purpose instead of the investment. For example, most of the recipients of MFIs are women (about 85-90\%). In many cases, husband or father or male member of the family insists the women in transferring the fund to the male member. Thus male member may use this fund for consumption, healthcare, or any other purposes instead of the investment. Conversely, the possibility of fund diversion in Islamic MFIs is almost impossible because of goods transfer. Thus, conventional MFIs again fail to fulfill the purpose of the Microfinance program.

f) Rebate for Timely Payment (as Reward): Islamic MFIs offer a discount on the profit rate for timely payment of the loan. On the contrary, such types of opportunity are absent in the conventional MFIs.

g) Charity: Moreover, Charity or Sadaqah is the permanent tool in the Islamic Microfinance institution because of using religious charity tools such as Zakah, Sadaqah, and many others. On the contrary, conventional MFIs do not use such an instrument; instead, these MFIs sometimes donate money based on the availability of the grants. But it is not permanent.

Table-4 illustrates and summarizes the evidence of deadweight losses through a comparison between the traditional (interest-based) and Islamic (interest-free) Microfinance program.

Table 4: The Evidences of Deadweight Loss: A Comparative Scenario

\begin{tabular}{|c|c|c|}
\hline Basis/Particulars & Conventional MFIs & Islamic MFIs \\
\hline Loan Interest rate & $\begin{array}{l}\text { Higher than the Islamic } \\
\text { MFIs } \\
20-35 \%\end{array}$ & $\begin{array}{l}\text { Profit rate: it is always } \\
\text { lower than the CMFIs. } \\
0-15 \% \\
\text { Profit rate on buying \& } \\
\text { selling }\end{array}$ \\
\hline Profit-Loss sharing & No & Yes \\
\hline Trade: buying \& selling & $\mathrm{No}$ & Yes \\
\hline $\begin{array}{l}\text { Interest free Loan/ } \\
\text { benevolent loan/ Qard al- } \\
\text { hasanah }\end{array}$ & No & Yes \\
\hline Real asset building & May be, may not be & Must \\
\hline Fund/Loan diversion & Easy & Impossible \\
\hline
\end{tabular}


Deadweight Loss in the Interest-based and the Interest-Free (Islamic) Microfinance Programs: A Comparative Analysis

\begin{tabular}{|l|l|l|}
\hline $\begin{array}{l}\text { Funding for the extremely } \\
\text { poor }\end{array}$ & No option & $\begin{array}{l}\text { Incorporated by the Zakah } \\
\text { and Sadaqah. Then } \\
\text { participated in the main } \\
\text { stream microfinance model }\end{array}$ \\
\hline Loan Sanctions method & Money in Cash & Products or Materials \\
\hline $\begin{array}{l}\text { Subtractions from the } \\
\text { Sanctioned Loan at } \\
\text { beginning }\end{array}$ & Yes & No \\
\hline $\begin{array}{l}\text { Rebate for timely payment } \\
\text { (as Reward) }\end{array}$ & No & Yes \\
\hline Charity & $\begin{array}{l}\text { Optional: Based on available } \\
\text { grants' fund disbursed by } \\
\text { the donors }\end{array}$ & Mandatory: Zakah, Sadaqah \\
\hline
\end{tabular}

Sources: compiled by the author from the different sources

\subsection{Evidences of the Deadweight Loss in the Conventional MFIs: Diagrammatic Presentation}

This section exposes the evidence of the deadweight loss regarding consumer' surplus, producer' surplus, and the quantity demanded of the Microfinance loan. The detailed calculations of the loan price or the interest rate, consumer' surplus, producer' surplus are given in the Box-1.

\section{a) The Deadweight Loss in Terms of Consumer' Surplus (CS):}

Figure 8: The Deadweight Loss in terms of Consumer Surplus

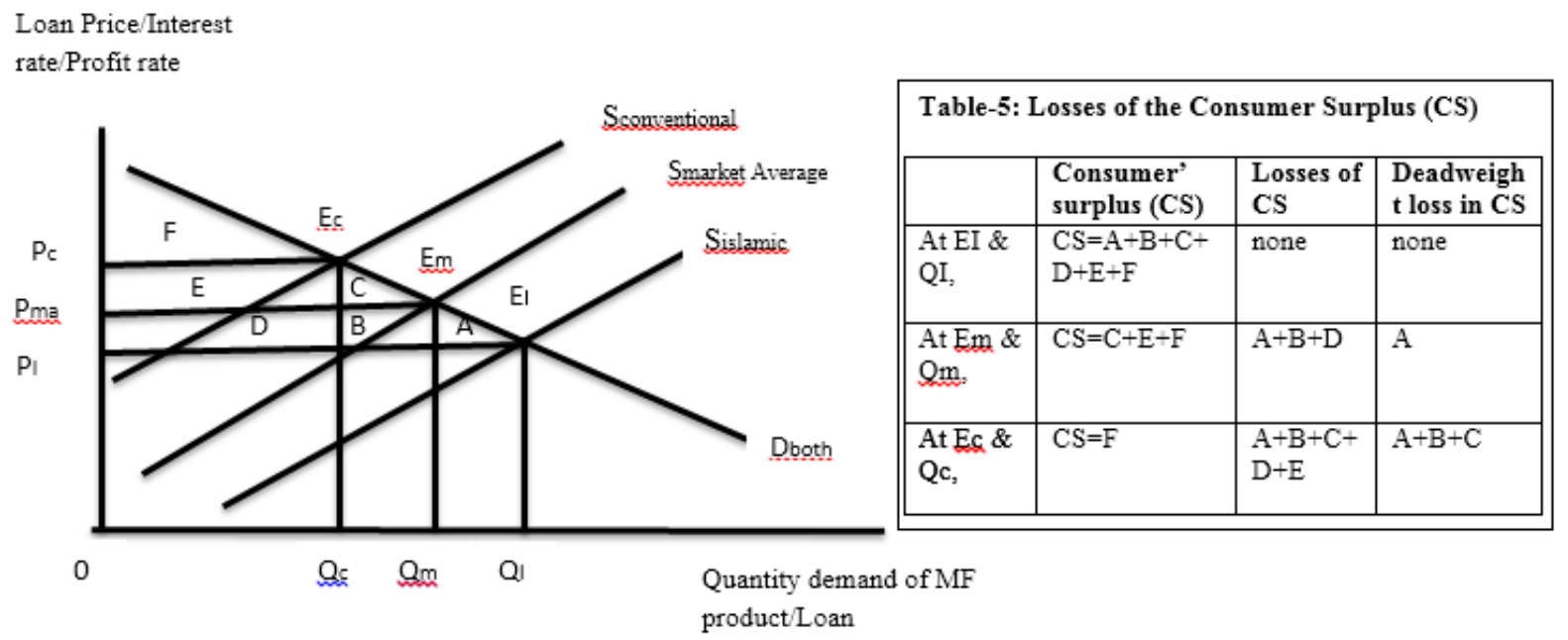

Sconventional= Supply curve of the conventional MFIs

SIslamic $=$ Supply curve of the Islamic MFIs (if all of the Islamic and the conventional MFIs provide Microfinance services at the Islamic loan prince) 
Smarket Average $=$ Supply curve of the market

Dboth= Demand curve of the market

$\mathrm{P}_{\mathrm{c}}=$ The average loan price of the conventional MFIs. It is calculated through the arithmetic mean of maximum and the minimum loan price of the traditional MFIs. That is (maximum loan price of traditional MFIs + Minimum loan price of conventional MFIs) /2.

Pma $=$ Average loan price of the market that is determined by the arithmetic mean of conventional and Islamic loan price. Besides, in this graph, the average maximum loan price is assumed as the market loan price.

$\mathrm{PI}=$ The average loan price of Islamic MFIs that is calculated through the arithmetic mean of maximum and the minimum loan price of the Islamic MFIs. That is (maximum loan price of Islamic MFIs + Minimum loan price of Islamic MFIs) /2.

Description: The figure- 8 and Table- 5 reveal the evidence of the deadweight loss in the form of the consumer' surplus. At the Islamic loan price (PI), the consumer surplus is $\mathrm{A}+\mathrm{B}+\mathrm{C}+\mathrm{D}+\mathrm{E}+\mathrm{F}$. At the market price $(\mathrm{Pma})$, the consumer' surplus is $\mathrm{C}+\mathrm{E}+\mathrm{F}$, and the traditional price $(\mathrm{Pc})$, the consumer' surplus is the only $\mathrm{F}$.

Moreover, at the market price the deadweight loss regarding the consumer' surplus is A. Also, at the traditional loan price $(\mathrm{Pc})$, the lost consumer' surplus is $\mathrm{A}+\mathrm{B}+\mathrm{C}+\mathrm{D}+\mathrm{E}$, and the deadweight loss is $\mathrm{A}+\mathrm{B}+\mathrm{C}$. So, it can be decided that, regarding loan price, the conventional Microfinance produces the maximum burden or welfare loss or deadweight loss compared to the loan price of Islamic MFIs.

\section{b) The Deadweight Loss in Terms of the Quantity Demanded (Qd)}

However, the deadweight loss is also high in terms of quantity demanded of the Microfinance loan. The quantity demand of Islamic Microfinance loan is higher than the quantity demand at market loan price and the quantity demand of conventional Microfinance loan. On the contrary, the loan price or interest rate or profit rate is lower in the Islamic Microfinance loan than the market rate and the conventional rate. Table-6 presented that, the deadweight loss is Qc- QI in terms of the Quantity demand (Qd). Therefore Islamic microfinance is superior to traditional microfinance program.

Table 6: Deadweight Losses in terms of the Quantity demand (Qd) and the Loan Price (P)

\begin{tabular}{|c|c|c|c|c|c|c|}
\hline \multicolumn{3}{|c|}{$\begin{array}{l}\text { Deadweight Losses in terms of the } \\
\text { Quantity demand (Qd) }\end{array}$} & \multicolumn{4}{|c|}{$\begin{array}{l}\text { Deadweight Losses in terms of the Loan } \\
\text { Price (P) }\end{array}$} \\
\hline $\begin{array}{l}\text { Qd of } \\
\text { Islamic } \\
\text { Microfin } \\
\text { ance } \\
\text { Loan }\end{array}$ & $\begin{array}{l}\text { Qd of } \\
\text { Microfin } \\
\text { ance } \\
\text { Loan at } \\
\text { market } \\
\text { Average } \\
\text { price }\end{array}$ & $\begin{array}{l}\text { Qd of } \\
\text { Conventi } \\
\text { onal } \\
\text { Microfin } \\
\text { ance } \\
\text { Loan }\end{array}$ & $\begin{array}{l}\text { Price of } \\
\text { Islamic } \\
\text { Microfin } \\
\text { ance } \\
\text { Loan }\end{array}$ & $\begin{array}{l}\text { Price of } \\
\text { Microfin } \\
\text { ance } \\
\text { Loan at } \\
\text { market } \\
\text { Average } \\
\text { price }\end{array}$ & $\begin{array}{l}\text { Price of } \\
\text { Conventi } \\
\text { onal } \\
\text { Microfin } \\
\text { ance } \\
\text { Loan }\end{array}$ & \\
\hline
\end{tabular}


Deadweight Loss in the Interest-based and the Interest-Free (Islamic) Microfinance Programs: A Comparative Analysis

\begin{tabular}{|l|l|l|l|l|l|l|l|}
\hline Qd & OQI & OQm & OQc & OPI & OPma & OPc & $\begin{array}{l}\text { Loan } \\
\text { Price }\end{array}$ \\
\hline $\begin{array}{l}\text { Losses } \\
\text { of Qd }\end{array}$ & - & Qm-QI & Qc- QI & - & - & - & \\
\hline $\begin{array}{l}\text { Compari } \\
\text { son in } \\
\text { term of } \\
\text { Qd }\end{array}$ & $\begin{array}{l}\text { OQI }>\text { OQm }>\text { OQc } \\
\text { Islamic Microfinance is better }\end{array}$ & $\begin{array}{l}\text { OPI }<\text { OPma }<\text { OPc } \\
\text { Islamic Microfinance is better }\end{array}$ & $\begin{array}{l}\text { Compari } \\
\text { son in } \\
\text { term of } \\
\text { price }\end{array}$ \\
\hline
\end{tabular}

c) The Deadweight Loss in Terms of the Producer Surplus (PS):

Figure 9: The Deadweight Loss regarding Producer Surplus (PS):

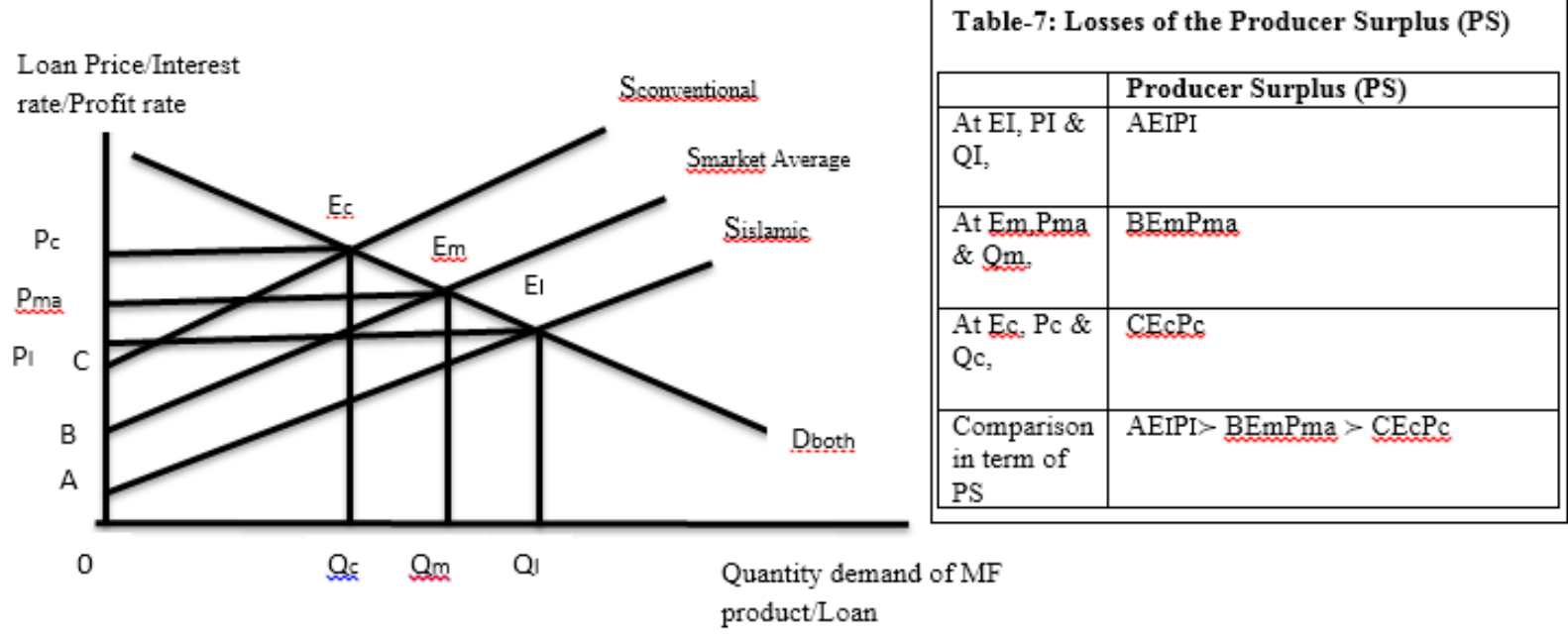

Figure-9 and Table-7 disclose that producer surplus is also higher in Islamic Microfinance (AEIPI) than conventional Microfinance program (CEcPc). It is the evidence of the deadweight loss in the producer surplus (PS) under the traditional Microfinance.

\section{Summary of Findings}

The key findings of this paper are:

a) Deadweight loss is alarmingly higher (at least three times) in the conventional Microfinance regarding consumer' surplus.

b) Producer' surplus is higher in the Islamic Microfinance than the interest-based Microfinance

c) The loan price is at least $142 \%$ (Bangladesh) and $241 \%$ (world) higher in conventional Microfinance than the Islamic Microfinance.

d) The quantity demand of the Microfinance loan is higher in the Islamic Microfinance than the traditional Microfinance. 
e) Islamic Microfinance has many excellent tools such as profit-loss sharing system, Quard Hasan or interest-free loan, Zakah, and Sadaqah. On the contrary, these are absent in conventional Microfinance

f) Islamic Microfinance is highly responsible for building the real asset, whereas the traditional Microfinance insignificantly contributes to it.

g) Fund diversion is the common phenomenon in the conventional Microfinance whereas it is almost impossible in the Islamic Microfinance

h) Finally, Islamic Microfinance is highly consumer-friendly and efficient than the traditional Microfinance, because it offers lower loan price, interest-free loan and religious charity tools, etc.

\section{Policy Recommendations:}

This paper recommends that,

a) Since the excess burden is higher in the conventional Microfinance, so traditional Microfinance Institutions should eliminate the interest and use the tools of Islamic Microfinance.

b) Islamic MFIs should propagate the superiority of Islamic Microfinance in society and should offer research grants to do research on it for future expansion.

c) Islamic MFIs should increase its coverage by managing funds from different sources.

d) Since there is strong proof that, in Bangladesh and the other countries of the world, conventional banks have been converted to Islamic banking. In the same way; to achieve the higher level of welfare of Islamic Microfinance program, the Microfinance regulatory authority of Bangladesh; and other countries should encourage and offer facilities to convert the conventional Microfinance institutions into Islamic Microfinance institutions.

\section{Conclusion}

Islamic Microfinance has first rated Islamic financial and charitable tools such as profit-loss sharing system, Sadaqah, Zakah, and Waqf. This paper investigates the operations of conventional and Islamic Microfinance program, then presented the deadweight loss/welfare loss/ excess burden in the traditional microfinance in the forms of consumer' and producer' surplus, loan price and the quantity demanded of a Microfinance loan. This paper found that consumer' surplus is at least three times lower in the conventional Microfinance program; producer surplus is higher in the Islamic Microfinance than the traditional Microfinance. The loan price is at least $142-241 \%$ higher in conventional Microfinance than the Islamic Microfinance. Hence, the quantity demand for Microfinance loan is higher in the Islamic Microfinance than the traditional Microfinance. This is why this paper recommends for converting the conventional Microfinance program into the Islamic Microfinance program. 
Deadweight Loss in the Interest-based and the Interest-Free (Islamic) Microfinance Programs: A Comparative Analysis

\section{References}

Abdullah, M. F., Amin, M.R., Ab Rahman, A. (2017), Is there any difference between Islamic and conventional Microfinance? Evidence from Bangladesh, International Journal of Business and Society, 18 (1): 97-112

Ahmed, Habib (2002)., Financing microenterprises: an analytical study of Islamic microfinance institutions, Islamic Economic Studies, 9(2), 27-63

Akhter, Dr.Waheed., Akhtar, Dr. Nadeem.,and Ali Jaffri, Syed Khurram.,(2009), Islamic microfinance and poverty alleviation: A case of Pakistan, Proceedings $2 n d C B R C$, Lahore, Pakistan,1-8

Akhuwat (2018), loan products offered, retrieved 18 December, 2018 from: https://www.akhuwat.org.pk/loan-products/

Al-arafah (2018), Microfinance, retrieved from https://al-arafahbank.com/Micro-Finance.php

Al-Falah (2018), Al-Falah Aam Unnayan Sangstha (AFAUS) সম্পর্ক, retrieved from http://www.dinajpurngos.com/ngos/index/alfalah_

Alamgir, H. Dewan A., Hassan, M. K. \& Dewan, H. H. (2011, December), A Comparative Review of Islamic Versus Conventional Microfinance In Bangladesh, paper presented at the $8^{\text {th }}$ International Conference on Islamic Economics and Finance, organized by the Center for Islamic Economics and Finance, Qatar Faculty of Islamic Studies, Qatar Foundation. Doha: Qatar

ASA (2018), Loan Products, retrieved from: http://www.asa.org.bd/loan-products/

Ashraf,Ali; Hassan, M.Kabir and Hippler III, William.J (2014), "Performance of microfinance institutions in Muslim countries, Humanomics, 30(2), 162-182

Badruddoza, S (2011, October), "Microfinance in Bangladesh: Red and Green Lights", paper presented at the Department of International Relations, University of Dhaka, Dhaka. Retrieved from https://www.slideshare.net/badruddoza/Microfinance-in-bangladeshred-and-green-lights

Ben Abdelkader, I. \& Ben Salem, A. (2013), Islamic vs. Conventional Microfinance Institutions: Performance analysis in MENA countries, International Journal of Business and Social Research (IJBSR), 3 (5): 219-233

Bishop, M. (2004), Essential Economics, London: the Economist and Profile Books Ltd

Black, J. (1997), A dictionary of economics, UK: Oxford University Press

BRAC (2018), Microfinance; retrieved 27 December 2018, from: http://www.brac.net/program/microfinance/ 
Bui, N. (2013), "Different Uses of Microfinance among Conventional and Islamic Borrowers: Evidence from Jordan". Master's Theses. Retrieved from https://repository.usfca.edu/thes/64

Buro (2018), Microfinance loan product, retrieved from: http://burobd.org/remittanceprogram.php?id=11

Card Bank (2017), Annual Report 2017, Interest rate, pp.73, retrieved 19 December 2018, from: https://cardbankph.com/wp-content/uploads/2018/07/Annual-Report-2017-CARDBank-Inc..pdf

Ebdaa bank (2018); Our financial products; retrieved 28 December 2018; http://ebdaabanksd.net/en/services.php

Economics times (2018), Definition of Deadweight Loss, retrieved from https://economictimes.indiatimes.com/definition/deadweight-loss

El-Komi, Mohamed (2013), Experiments in Islamic microfinance, Journal of economic Behavior E Organization, 95, 252-269

Enterprise 54 (2014), How to Access Loans without Collateral, retrieved 11 December, from: http://enterprise54.com/how-to-access-loans-without-collateral/

Exim bank (2018), Agricultural \& Rural investment, retrieved from http://www.eximbankbd.com/agri/agri_banking

FINCA (2018), Microfinance; retrieved 27 December 2018, from: https://finca.org/ourwork/microfinance/

GIFR (2017), Global Islamic Finance Report (GIFR 2017), retrieved from http://www.gifr.net/publications/gifr2017/intro.pdf

Giadorou Koch, L. (2015), Interest Rate Debate in Microfinance: Reflections on regulated caps, retrieved from:http://www.mftransparency.org/interest-rate-debate-in-microfinancereflections-on-regulated-caps/

Gonzalez, Adrian (2008), How Many MFIs and Borrowers Exist? Updated Dec, 2008, retrieved 23 October, 2018 from: https://www.themix.org/sites/default/files/publications/How\%20Many\%20Borrowers\% 20and\%20MFIs\%20Exist\%2012-31-2008_0.zip

Grameen (2018a), what is Microcredit, retrieved 12 December 2018, from: http://www.grameen.com/what-is-microcredit/

Grameen (2018), Credit Lending Models; retrieved 12 December 2018, from: http://www.grameen.com/credit-lending-models/

Grameen koota (2018), Products and Services, retrieved 19 December 2018, from: https://www.grameenkoota.org/index.php/products-and-services/financialproducts/group-lending/income-generation-loans/ 
Deadweight Loss in the Interest-based and the Interest-Free (Islamic) Microfinance Programs: A Comparative Analysis

Haneef, M.A; Muhammad, A.D.;Pramanik,A.H and Mohammed .M.O. (2014), Integrated Waqf Based Islamic Microfinance Model (IWIMM) for Poverty alleviation in OIC Member Countries, Middle-East Journal of Scientific Research, 19 (2): 286-298

Hossain, Basharat (2019), Islamic Microfinance and Rehabilitation Model for the

Slum and Floating Population by Waqf Funds, the Case of Bangladesh:

A Proposal for Muslim Countries, JKAU: Islamic Econ., 32 (2),139-160, DOI:10.4197/Islec. 322.11

IBBL (2018), RDS spotlights, retrieved on February 9, 2018 from http://www.islamibankbd.com/rds/

Inm (2016), Interest Rates in Bangladesh Microcredit Market, Policy brief by Institute of Microfinance (Inm). Retrieved from: http://inm.org.bd/wpcontent/uploads/2016/01/Interest-Rate.pdf

Islami bank, (2018), Investment Modes, retrieved 15 December 2018, from: https://www.islamibankbd.com/rds/modes_of_investment.php

Islami bank, (2018), Investment Modes, retrieved 15 December 2018, from: https://www.qmb.ir/Index.aspx?page_=form\&lang=2\&sub=0\&tempname=ENShow\&Pa geID=1275\&isPopUp=False

Islamic Relief (2018); Livelihood and community development; retrieved 28 December 2018; from: http://www.islamic-relief.org.bd/programmes/livelihood/

Islamic Relief (2018a); Islamic Microfinance; retrieved 28 December 2018; from: https://islamicrelief.org.pk/what-we-do/islamic-microfinance/

Ismail, Verni Yuliaty. Zain, Efendy and Zulihar, Zulihar (2015), the Optimization of Human Resource's Performance in Islamic Microfinance Institutions through Job Analysis and Competency Model, Asian Journal of Technology Management , 8 (1); 56-67

Iqbal, Z. \& Mirakhor, A. (2014), Economic Development and Islamic Finance, Islamic Economic Studies, 22 (1):213-215

ISRA, (2012), Islamic Financial System: Principles \& Operations, International Shari'ah Research Academy for Islamic Finance (ISRA), Edited by Asyraf Wajdi Dato' Dusuki, chapter-12, Section 2: Operational Framework of Takaful,pp.13-29, Malaysia: ISRA retrieved from: http://irep.iium.edu.my/14472/1/Chp_12.pdf

Khan, Muhammad Akram (1990), Islamic Economics and Finance: A Glossary, 2nd edition, 26, 41, 49, 61,151, New York: Routledge

Laxman Karve, Shrikrishna (2009), Principles of Life Insurance, chapter-4, Life insurance policies, pp, 57-88 Mumbai: Himala va publishing house pvt. Ltd. 
Lead foundation (2016), 2016 Audited Financial Report, Lending revenue, pp.7, retrieved 19 December 2018, from: https://lead.org.eg/application/files/2614/9499/7688/2016report.PDF

Ledgerwood, J. (2000), Microfinance handbook: an institutional and financial perspective, Washington, D.C: The International Bank for Reconstruction and Development/The World Bank.

Mahmood, Hafiz Zahid; Khan, Roheel; Mehmood, Bilal and Khan, Muhammad (2014), Efficiency Analysis of Conventional vs. Islamic Microfinance: An Appraisal for Sustainability in Pakistan, International Journal of Empirical Finance, 3 (4 ),192-201

Mannan, A.M. (2015), Islamic Microfinance: Bangladesh Experience, retrieved from www.irti.org/English/.../Islamic\%20Microfinance-Bangladesh\%20Experience.pdf

Mankiw, N.G (2014), Principles of Microeconomics, London: South-Western College Pub

Masyita, Dian and Ahmed, Habib (2011), Why is Growth of Islamic Microfinance Lower than Conventional? A Comparative Study of the Preferences and Perceptions of the Clients of Islamic and Conventional Microfinance Institutions' in Indonesia, Conference paper, 8th International Conference on Islamic Economics and Finance: 19-21 December 2011, Qatar: Doha, retrieved 17 July 2019 from: http://www.iefpedia.com/english/wpcontent/uploads/2011/12/Dian-Masyita.pdf

MBK (2018), Products, retrieved 19 December 2018, from: https://www.mbkventura.com/products.php

MRA (2018), List of Licensed MFIs as of May 27, 2018, Microfinance Regulatory Authority, Dhaka Bangladesh, Retrieved from: http://www.mra.gov.bd/images/Licensed_NGO_MFIs/lic27052018en.pdf

Mughal, Muhammad Zubair (2017), Islamic Agri \& Rural Finance, retrieved 2 November 2018 from: Islamic Agri. Finance 7th gimf.pptx

Muslim Aid (2018), economic empowerment, retrieved from https://www.muslimaid.org/what-we-do/economic-empowerment/

Norma, Bt Md Saad, (2012), Microfinance and Prospect for Islamic Microfinance Products: The Case of Amanah Ikhtiar Malaysia Advances in Asian Social Science, 1(1), 27-33

Obaidullah, Mohammed (2008), Introduction to Islamic Microfinance, IBF Net (P) Limited, India: New Delhi.

Obaidullah, Mohammed., and Khan, Tariqullah (2008), Islamic microfinance development challenges and initiatives, Policy Dialogue Paper No. 2 , Islamic Development Bank, 2008, Soudi Arabia: Jeddah

Qarz Al-Hasaneh Mehr Iran Bank, (2017), Gharz Al-Hasanah loan, retrieved 15 December 2018, from: https://www.islamibankbd.com/rds/saving_plan.php 
Deadweight Loss in the Interest-based and the Interest-Free (Islamic) Microfinance Programs: A Comparative Analysis

QMB (2018), Gharz Al-Hasanah loan, retrieved 18 December, 2018 from: https://www.qmb.ir/Index.aspx?page_=form\&lang=2\&sub=0\&tempname=ENShow\&Pa geID=1237\&isPopUp=False

Rahman, Abdul Rahim Abdul (2010), Islamic microfinance: an ethical alternative to poverty alleviation, Humanomics, 26(4), 284-295

Rahman, Abdul Rahim ABDUL. (2007)., Islamic Microfinance: A Missing Component in Islamic Banking, Kyoto Bulletin of Islamic Area Studies, 1(2) : 38-53

Rashad, D. S. (2014), New trends in global Islamic Microfinance, retrieved from www.kantakji.com/strategic.../new-trends-in-global-islamic-Microfinance.aspx?...true

Rejda, George E. and McNamara, Michael (2013), Principles of Risk Management and Insurance, chapter-6, Insurance and company operation, pp, 103-122 New York: Pearson

Riwajanti, Nur Indah (2013), Islamic Microfinance as an Alternative for Poverty Alleviation: A Survey, Afro Eurasian Studies, 2 (1-2): 254-271

Rosenberg, R. Gaul, S.Ford,W.\& Tomilova,O (2013), Microcredit Interest rate and their determinants (2004-2011), Washington D.C.: CGAP,MIX,KFW. Retrieved from: http://documents.worldbank.org/curated/en/125451468337250939/pdf/819920WP0CGA P00Box0379855B00PUBLIC0.pdf

Sadegh, B. (2009), 'Islamic Microfinance, Providing Credit to the Poor: A Case Study of Iran', International Economics Studies, 34(1):99-107

Saaid Ali, Abd Elrahman Elzahi (2015), Islamic microfinance: moving beyond financial inclusion, European Scientific Journal, 11 (10): 1857 - 7881

Samuelson, P.A. \& Nordhaus, W.D. (2010), Economics, New York: The McGraw-Hill Companies, Inc.,

Samuelson, W. F. \& Stephen G. M. (2011), Managerial economics, USA: John Wiley \& Sons, Inc. USA

Seibel, Hans Dieter (2008), Islamic Microfinance in Indonesia: The Challenge of Institutional Diversity, Regulation, and Supervision, Journal of Social Issues in Southeast Asia 23(1): 86103

Shakti (2018), microloan, retrieved from: http://www.sfdw.org/microfinance/

SSNF (2018), Social Safety Net Foundation, retrieved from https://web.facebook.com/pg/bdssnf/about/?ref=page_internal

The Consultative Group to Assist the Poor (CGAP) (2017), 'Islamic Microfinance:

An Emerging Market Niche', retrieved from 470010ENGLISH01PUBLIC10FocusNote149.pdf

The daily Star (2015), SIBL cares about social causes, retrieved from

http://www.thedailystar.net/business/sibl-cares-about-social-causes-785437 
The daily star (2017), Islamic Microfinance to deepen financial inclusion, retrieved from http://www.thedailystar.net/business/islamic-Microfinance-deepen-financial-inclusion1359862

TMSS (2018), TMSS Islamic Microfinance (TIMF), Retrieved from http://tmss-bd.org/tmssislamic-Microfinance-timf

Ubaidullah, Mohammed (2007), Role of Microfinance in Poverty Alleviation: Lessons from Experiences in Selected IDB Member Countries, Jeddah: Islamic Research \& Training Institute

United Nations Development Programme (2010), scaling up Islamic Microfinance in Bangladesh through the Private Sector: Experience of Islami Bank Bangladesh Limited (IBBL), retrieved from http://www.undp.org/content/dam/undp/library/Poverty\%20Reduction/Participatory \%20Local\%20Development/Bangladesh_D10_web.pdf

Vitas Lebanon (2018); Loans; retrieved 28 December 2018; http://www.vitaslebanon.com/loans/personal-loans

Wajdi Dusuki, Dr. Asyraf (2007)., Banking for the Poor: The Role of Islamic Banking in Microfinance Initiatives, Proceedings of the 2nd Islamic Conference 2007 (iECONS2007) organized by Faculty of Economics and Muamalat, Islamic Science University of Malaysia.

Wasil foundation (2018), Publication, retrieved 19 December 2018, from: http://www.wasil.org.pk/Knowledge-Center/Poverty-to-Profit-IslamicMicrofinance.pdf

Webster, T.J. (2003), Managerial Economics: Theory and Practice, New York: Academic Press

Widiarto, Indra and Emrouznejad, Ali (2015), Social and financial efficiency of Islamic microfinance institutions: A Data Envelopment Analysis application, Socio-Economic Planning Sciences, 50, 1-17, https://doi.org/10.1016/j.seps.2014.12.001

Wilson, Rodney (2007)., Making development assistance sustainable through Islamic microfinance, IUM Journal of Economics and Management,15(2): 197-217

Yunus, M (2018), Grameen bank at a glance, retrieved from: http://muhammadyunus.org/index.php/design-lab/previous-design-labs/37about/about/371-grameen-bank-at-a-glance 


\section{Appendix:}

Box-1: Calculations of the loan price or the interest rate, Consumer Surplus, Producer surplus

a) $\mathrm{Pc}=$ the average loan price of the conventional MFIs.

$\mathrm{Pc}_{\mathrm{c}}=($ maximum investments interest rate + minimum investment interest rate $) / 2$

$=(33+15) / 2$

$=24$

b) $\mathrm{PI}=$ the average loan price of Islamic MFIs

$\mathrm{PI}=($ maximum investment profit rate + minimum profit rate $) / 2$

$=(15+0) / 2$

$=7.5$

c) Pma= loan price of the market average

$\mathrm{Pma}=(\mathrm{PC}+\mathrm{PI}) / 2$

$=(24+7.5) / 2$

$=15.75$

d) Consumer surplus (CS):

$\mathrm{CS}$ at $\mathrm{Pc}=$ willingness to pay by consumer $-\mathrm{Pc}$

CS at Pma=willingness to pay by consumer - Pma

CS at PI=willingness to pay by consumer $-\mathrm{PI}$

e) Producer surplus (PS):

$\mathrm{PS}$ at $\mathrm{Pc}=\mathrm{PC}-$ cost of producer

PS at Pma=Pma - cost of producer

PS at PI=PI - cost of producer 